OPEN ACCESS

Indonesian Journal of Human Nutrition
P-ISSN 2442-6636
E-ISSN 2355-3987

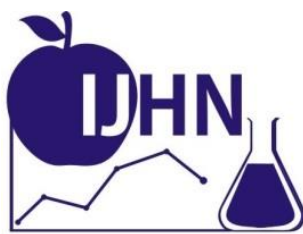

www.ijhn.ub.ac.id

Artikel Hasil Penelitian

\title{
Niat dan Perilaku Pemilihan Jajanan Anak Sekolah yang Mendapat Pendidikan Gizi Metode Ceramah dan TGT
}

\author{
(Attitude of School Aged Children Toward Snacking Intention Using Lecture Method \\ in Comparison With TGT Method)
}

\author{
Ida Sri Maduretno ${ }^{1}$, Nanik Setijowati ${ }^{2}$ dan Nia Novita Wirawan ${ }^{1}$ \\ 1 Program Studi Ilmu Gizi Fakultas Kedokteran Universitas Brawijaya \\ Laboratorium Ilmu Kesehatan Masyarakat Fakultas Kedokteran Universitas Brawijaya \\ * Alamat korespondensi, E-Mail: ida.s.madu@gmail.com
}

Diterima: / Direview: / Dimuat: Oktober 2014 / November 2014 / Juni 2015

\begin{abstract}
Abstrak
Siswa sekolah dasar merupakan kelompok yang rentan terhadap keracunan makanan. Metode ceramah merupakan metode sederhana dan sering digunakan dalam pendidikan gizi, tetapi responden cenderung pasif, sedangkan metode Team Game Tournament (TGT) merupakan metode berbasis permainan menarik dan disukai anak SD. Tujuan penelitian ini adalah mengetahui perbedaan niat dan perilaku pemilihan jajanan sehat pada siswa kelas 5 SDN Tumpakrejo 1 dan 2 menggunakan metode ceramah dan metode TGT. Desain penelitian yang digunakan adalah quasy experimental study dengan pre-test and post-test design. Jumlah sampel adalah 42 orang, yang diambil dengan cara total sampling yaitu memilih seluruh siswa kelas 5B SDN Tumpakrejo 1 sebagai kelompok TGT dan seluruh siswa kelas 5 SDN Tumpakrejo 2 sebagai kelompok ceramah. Variabel yang diteliti adalah niat, perilaku di sekolah dan rumah terkait pemilihan jajanan pada kedua kelompok berdasarkan pengukuran sebelum dan sesudah perlakuan. Hasil penelitian menunjukkan bahwa terdapat peningkatan niat yang signifikan pada kedua kelompok $(\mathrm{p}<0,05)$ tetapi tidak ada perbedaan niat yang signifikan antara kedua kelompok setelah diberi pendidikan gizi. Perilaku di sekolah menunjukkan adanya perbedaan yang signifikan pada kedua kelompok dan juga antara kedua kelompok setelah diberi pendidikan gizi. Tidak terdapat perbedaan perilaku di rumah yang signifikan pada kedua kelompok dan juga antara kedua kelompok setelah diberi pendidikan gizi. Berdasarkan hasil penelitian dapat disimpulkan bahwa metode ceramah lebih baik dalam meningkatkan niat, sedangkan TGT lebih baik dalam meningkatkan perilaku di sekolah walaupun kedua metode tersebut cukup efektif meningkatkan niat dan perilaku di sekolah. Namun kedua metode kurang efektif dalam meningkatkan perilaku jajanan di rumah.
\end{abstract}

Kata Kunci: pendidikan gizi, niat, perilaku, jajanan 


\begin{abstract}
Elementary school students is a group that is suspectible to suffer from food poisoning. Lecture is a simple method and frequently used in nutritional education, but respondent is passive when this method is used while Team Game Tournament (TGT) is an interesting playing-based method and preferred by elementary school children. The aim of this study was to determine the differences of snacking intention and behaviour of the fifth grade students in SDN Tumpakrejo 1 and 2 using lecture and TGT method. This research was a quasy experimental study with pre-test and post-test design. Forty two samples were recruited, by using total sampling, from all students in 5B at SDN Tumpakrejo 1 as TGT group and all fifth grade students at SDN Tumpakrejo 2 as lecture group. This research variables were snacking intention, behaviour in the school and home in both groups based on before-after measurements. The results showed that there was a significant improvement of intention in both groups $(p<0,05)$ but no significant difference of intention between groups after nutritional education was given. Snacking behaviour in the school had a significant difference in both groups and also between groups. But snacking behaviour in the home had no significant difference in both groups and also between groups. Based on the study finding, it was concluded that lecture improves intention more than TGT while TGT improves more snacking behaviour in the school although both methods were effective in improving snacking intention and behaviour in the school. Both were not effective in improving snacking behaviour in the home.
\end{abstract}

Keywords: nutrition education, intention, behaviour, snacks

\section{PENDAHULUAN}

Pangan jajanan memegang peranan penting dalam memberikan asupan energi dan zat gizi bagi anak usia sekolah yang akan menunjang pertumbuhan dan prestasi belajar anak sekolah. Survei yang dilakukan di Bogor pada tahun 2004 menyatakan bahwa sebanyak 36\% kebutuhan energi anak sekolah diperoleh dari pangan jajanan yang dikonsumsinya tetapi peranan strategis tersebut tidak diimbangi dengan mutu dan keamanan pangan jajanan yang baik [1].

Data pengawasan PJAS (Pangan Jajanan Anak Sekolah) yang dilakukan Direktorat Inspeksi dan Sertifikat Pangan Badan Pengawas Obat dan Makanan RI (BPOM RI) bersama Balai Besar/Balai POM di seluruh Indonesia pada tahun 2008-2010 menunjukkan bahwa 40-44\% PJAS tidak memenuhi syarat karena mengandung bahan kimia berbahaya seperti formalin, boraks, rhodamin, Bahan Tambahan Pangan (BTP) seperti siklamat dan benzoat yang melebihi batas aman serta cemaran mikrobiologi [1,2].

Sebuah penelitian terhadap siswa kelas 46 sekolah dasar di Taiwan terkait pemilihan jajanan sehat dan tidak sehat diketahui bahwa sekitar 21,9\% siswa jarang membeli jajanan tidak sehat, $68 \%$ siswa kadang-kadang serta $10,1 \%$ siswa cukup rutin membeli jajanan tidak sehat [3].

Pendidikan gizi bertujuan untuk mengubah perilaku konsumsi pangan menuju perilaku yang lebih baik yang diawali dengan pemberian informasi untuk meningkatkan pengetahuan anak untuk menimbulkan kesadaran dan menyebabkan perubahan perilaku $[4,5]$. Sebelum membentuk suatu perilaku diperlukan niat karena niat merupakan prediktor paling penting dan cepat dalam pembentukan perilaku. Niat diartikan sebagai faktor motivasi yang menunjukkan seberapa keras dan banyaknya usaha yang dilakukan anak dalam pemilihan jajanan sehat [6].

Usia anak yang paling tepat diberikan pendidikan gizi adalah usia 11 tahun karena pada usia tersebut anak berada dalam tahapan operasional formal yaitu anak mampu berpikir secara abstrak, menalar secara logis, dan menarik kesimpulan dari informasi yang tersedia [7].

Sebagian besar metode pendidikan gizi yang sering dilakukan adalah metode ceramah untuk meningkatkan pengetahuan gizi anak sekolah [8]. Pada metode ini penyuluh lebih dominan dalam memberikan materi, sedangkan responden lebih dominan mendengarkan. Metode ini lebih efisien dan sederhana tetapi seringkali 
responden cenderung pasif yang dapat menciptakan suasana pendidikan gizi yang monoton dan menyebabkan kebosanan [9].

Oleh karena itu diperlukan suatu metode pendidikan gizi yang dipadukan dengan permainan sehingga responden lebih aktif dan mampu mencegah timbulnya kebosanan. Pendidikan gizi dengan metode Team Game Tournament (TGT) merupakan salah satu metode yang mudah diterapkan, anak dilibatkan sebagai tutor teman sebaya, terdapat permainan, dan penghargaan sehingga anak dapat belajar lebih rileks, menumbuhkan tanggung jawab, kerja sama dalam kelompok, dan persaingan yang sehat serta keterlibatan anak secara aktif dalam pembelajaran [10].

Tujuan dari penelitian ini adalah untuk mengetahui perbedaan niat (intention) dan perilaku pemilihan jajanan sehat baik di sekolah maupun di rumah pada siswa kelas 5 SDN Tumpakrejo 1 dan 2 menggunakan metode ceramah dan Team Game Tournament (TGT).

\section{METODE PENELITIAN \\ Rancangan Penelitian}

Desain penelitian yang digunakan adalah quasy experimental study dengan pre-test and post-test design. Penelitian ini telah lolos etik dari Komisi Etik Penelitian Kesehatan Fakultas Kedokteran Universitas Brawijaya dengan No. 472/EC/KEPK-S1-GZ/10/2013.

\section{Sumber Data}

Pengambilan responden penelitian dilaksanakan di dua sekolah yaitu SDN Tumpakrejo 1 dan 2 Kabupaten Malang. Pelaksanaan penelitian dilakukan selama 3 bulan, yaitu bulan Agustus-Oktober 2013.

\section{Sasaran Penelitian}

Jumlah sampel adalah 42 orang, yang diambil dengan cara total sampling yakni dipilih semua siswa kelas 5B dari SDN Tumpakrejo 1 sebagai kelompok Team Game Tournament (TGT) dan seluruh siswa kelas 5 SDN Tumpakrejo 2 sebagai kelompok ceramah. Jumlah masing-masing siswa SD tersebut adalah 16 orang pada kelompok ceramah dan 26 orang pada kelompok Team Game Tournament (TGT).

\section{Teknik Pengumpulan Data}

Penelitian ini dibagi menjadi dua tahap kegiatan utama, meliputi studi pendahuluan menggunakan metode observasi dan wawancara untuk mengetahui pola konsumsi makanan jajanan, masalah terkait makanan jajanan, karakteristik sosial-ekonomi, materi pendidikan terkait gizi yang pernah diberikan pada siswa, dan karakteristik tingkat prestasi siswa SDN Tumpakrejo 1 dan SDN Tumpakrejo 2. Pelaksanaan penelitian utama berupa intervensi pada dua kelompok perlakuan yaitu berupa pendidikan gizi dengan metode ceramah dan TGT serta pelaksanaan pengukuran sebelum dan sesudah perlakuan.

Data mengenai niat siswa didapat dengan cara pemberian kuesioner niat yang berisi 14 pernyataan untuk sebelum dan sesudah perlakuan dan data mengenai perilaku siswa di sekolah didapat melalui observasi selama seminggu baik sebelum maupun sesudah perlakuan menggunakan lembar observasi (checklist) yang berisi 9 pernyataan yang disesuaikan dengan konten materi gizi yang terdapat di dalam pendidikan gizi dengan metode ceramah dan Team Game Tournament (TGT). Untuk data terkait perilaku siswa di rumah didapatkan melalui pencatatan snack diary selama seminggu yang dilakukan responden sebelum dan sesudah pemberian perlakuan. Seminggu sebelum dilakukan perlakuan kedua kelompok diberi kuesioner niat untuk mengetahui niat terkait pemilihan jajanan sehat, dilakukan observasi perilaku pemilihan jajanan serta diberikan snack diary. Setelah satu minggu, siswa kelas 5 SDN Tumpakrejo 2 diberi pendidikan gizi dengan metode ceramah sebanyak 3 kali pertemuan, sedangkan siswa kelas 5B SDN Tumpakrejo 1 diberi pendidikan gizi dengan metode Team Game Tournament (TGT) sebanyak 3 kali pemberian materi dengan penyuluhan. Jarak antara pengukuran awal dengan intervensi dilakukan sependek mungkin dimaksudkan untuk meminimalisasi terjadinya paparan-paparan dari luar sebelum intervensi dilakukan. Namun yang menjadi kelemahan adalah jika intervensi diadakan sesaat setelah pengukuran awal, maka kemungkinan besar akan terjadi interaksi antara pengukuran awal dan intervensi sehingga responden menjadi lebih sensitif terhadap isu yang ada serta akan menyebabkan responden mengingat soal pada pengukuran awal dan ingatannya ini akan mempengaruhi responnya terhadap intervensi dan pengukuran yang akan diadakan setelah intervensi [11]. Dalam hal ini pengukuran awal berupa pemberian kuesioner niat, pengamatan menggunakan lembar observasi, dan pencatatan snack diary. Pemberian kuesioner 
niat dan observasi perilaku setelah intervensi dilakukan 1 bulan setelah intervensi diberikan karena dengan waktu tersebut materi yang diberikan sudah mengendap dalam ingatan responden [12]. Selain itu snack diary juga dibagikan 1 bulan setelah intervensi dan pencatatan dilakukan selama 1 minggu.

\section{Teknik Analisis Data}

Data yang diperoleh diolah dan dianalisis menggunakan software SPSS 16 for Windows. Data identitas responden yang meliputi jenis kelamin dan umur responden dianalisis secara deskriptif dan menggunakan uji Mann Whitney untuk melihat perbedaan umur dan jenis kelamin antara kedua kelompok karena data jenis kelamin dan usia responden tidak terdistribusi normal. Data niat sebelum diberi pendidikan gizi dengan metode ceramah terdistribusi normal, sedangkan niat sesudah diberi pendidikan gizi dengan metode ceramah serta niat sebelum dan sesudah diberi pendidikan gizi dengan metode TGT tidak terdistribusi normal. Data selisih nilai niat responden pada kelompok ceramah dan TGT juga tidak terdistribusi normal. Uji yang digunakan adalah uji Wilcoxon untuk melihat perbedaan antara niat pemilihan jajanan sebelum dan sesudah diberi pendidikan gizi baik dengan metode ceramah maupun TGT. Uji Mann Whitney untuk melihat perbedaan niat pemilihan jajanan antara kedua kelompok baik sebelum maupun sesudah pemberian pendidikan gizi. Uji Mann Whitney untuk melihat perbedaan selisih nilai niat pemilihan jajanan sebelum dan sesudah diberi pendidikan gizi antara kedua kelompok.

Data perilaku jajanan di sekolah sebelum diberi pendidikan gizi dengan metode TGT terdistribusi normal, sedangkan perilaku responden sesudah diberi pendidikan gizi menggunakan metode TGT serta perilaku sebelum dan sesudah diberi pendidikan gizi dengan metode ceramah tidak terdistribusi normal. Data selisih nilai perilaku responden di sekolah pada kelompok ceramah dan TGT terdistribusi normal. Uji yang digunakan adalah uji Wilcoxon untuk melihat perbedaan antara perilaku pemilihan jajanan di sekolah sebelum dan sesudah diberi pendidikan gizi baik dengan metode ceramah maupun TGT. Uji Mann Whitney untuk melihat perbedaan perilaku pemilihan jajanan di sekolah antara kedua kelompok baik sebelum maupun sesudah pemberian pendidikan gizi. Uji Independent T-Test untuk melihat perbedaan selisih nilai perilaku pemilihan jajanan di sekolah sebelum dan sesudah diberi pendidikan gizi antara kedua kelompok.

Data perilaku jajanan di rumah sebelum dan sesudah diberi pendidikan gizi menggunakan metode ceramah dan TGT tidak terdistribusi normal. Data selisih nilai perilaku jajanan di rumah pada kelompok TGT juga tidak terdistribusi normal tetapi pada kelompok ceramah terdistribusi normal. Uji yang digunakan meliputi uji Wilcoxon untuk melihat perbedaan antara perilaku pemilihan jajanan di rumah sebelum dan sesudah diberi pendidikan gizi baik dengan metode ceramah maupun TGT. Uji Mann Whitney untuk melihat perbedaan perilaku pemilihan jajanan di rumah antara kedua kelompok baik sebelum maupun sesudah pemberian pendidikan gizi.Uji Mann Whitney untuk melihat perbedaan selisih nilai perilaku di rumah sebelum dan sesudah diberi pendidikan gizi antara kedua kelompok.

Hasil yang ada menggambarkan perbedaan yang bermakna atau tidak. Penelitian ini menggunakan derajat kepercayaan sebesar $95 \%, \alpha=0,05$, maka bermakna bila $\mathrm{p} \leq 0,05$.

\section{HASIL PENELITIAN}

Responden pada penelitian ini adalah siswa kelas 5B SDN Tumpakrejo 1 sebagai kelompok Team Game Tournament (TGT) dan siswa kelas 5 SDN Tumpakrejo 2 sebagai kelompok ceramah.

\section{Karakteristik Responden Penelitian Usia Responden Penelitian}

Usia responden pada penelitian ini berada pada rentang usia 10 hingga 12 tahun. Baik pada kelompok ceramah maupun kelompok Team Game Tournament (TGT) sebagian besar responden berusia 11 tahun yaitu masing-masing sebanyak $93,8 \%$ dan $65,4 \%$. Responden yang berusia 12 tahun pada kelompok ceramah dan kelompok Team Game Tournament (TGT) masing-masing sebanyak $0 \%$ dan 15,4\%. Pada tabel tersebut juga dapat diketahui besar nilai $\mathrm{p}=0,917 ; \mathrm{p}>0,05$ yang menunjukkan bahwa tidak ada perbedaan yang signifikan terkait usia responden antara kelompok ceramah dan TGT (Tabel 1). 
Tabel 1. Distribusi Responden Berdasarkan Usia

\begin{tabular}{lccccc}
\hline \multirow{2}{*}{ Usia } & \multicolumn{2}{c}{ Ceramah } & \multicolumn{2}{c}{ TGT } & $\boldsymbol{P}$ \\
\cline { 2 - 6 } & $\mathbf{n}$ & $\mathbf{\%}$ & $\mathbf{n}$ & $\boldsymbol{\%}$ & \\
\hline 10 tahun & 1 & 6,2 & 5 & 19,2 & 0,917 \\
11 tahun & 15 & 93,8 & 17 & 65,4 & \\
12 tahun & 0 & 0,0 & 4 & 15,4 & \\
Total & 16 & 100,0 & 26 & 100,0 & \\
\hline
\end{tabular}

\section{Jenis Kelamin Responden Penelitian}

Tabel 2 menunjukkan bahwa dari 16 responden pada kelompok ceramah 9 orang diantaranya berjenis kelamin laki-laki dengan persentase sebesar $56,2 \%$ dan 7 orang berjenis kelamin perempuan dengan persentase $43,8 \%$.

Kelompok Team Game Tournament (TGT) berjumlah 26 responden, yaitu terdapat 14 orang berjenis kelamin laki-laki atau sebesar 53,8\% dan 12 orang berjenis kelamin perempuan atau sebesar 46,2\%.

Pada tabel di bawah ini juga dapat diketahui besar nilai $p=0,881 ; p>0,05$ yang menunjukkan bahwa tidak ada perbedaan yang signifikan terkait jenis kelamin responden antara kelompok ceramah dan TGT (Tabel 2).

Tabel 2. Distribusi Responden Berdasarkan Jenis Kelamin

\begin{tabular}{lccccc}
\hline \multirow{2}{*}{$\begin{array}{c}\text { Jenis } \\
\text { Kelamin }\end{array}$} & \multicolumn{2}{c}{ Ceramah } & \multicolumn{2}{c}{ TGT } & $\boldsymbol{P}$ \\
\cline { 2 - 6 } & $\mathbf{n}$ & $\mathbf{\%}$ & $\mathbf{n}$ & $\boldsymbol{\%}$ & \\
\hline Laki-laki & 9 & 56,2 & 14 & 53,8 & 0,881 \\
Perempuan & 7 & 43,8 & 12 & 46,2 & \\
Total & 16 & 100,0 & 26 & 100,0 & \\
\hline
\end{tabular}

\section{Niat Responden Penelitian}

Niat Sebelum dan Sesudah Diberi Pendidikan Gizi dengan Metode Ceramah dan TGT

Tabel 3 menunjukkan bahwa terjadi peningkatan nilai niat sebelum dan sesudah pemberian pendidikan gizi dengan metode ceramah, peningkatan ini memiliki perbedaan yang signifikan $(\mathrm{p}=0,01 ; \mathrm{p}<0,05)$. Hasil analisis tersebut menunjukkan bahwa ada perbedaan yang signifikan terkait niat pemilihan jajanan sehat sebelum dan sesudah diberi pendidikan gizi dengan metode ceramah. Median nilai niat meningkat setelah diberi pendidikan gizi dengan metode ceramah. Pada kelompok Team Game Tournament (TGT) menunjukkan bahwa terjadi peningkatan nilai niat sebelum dan sesudah pemberian pendidikan gizi dengan metode Team Game Tournament (TGT), peningkatan ini memiliki perbedaan yang signifikan $(\mathrm{p}=0,027$, $\mathrm{p}<0,05)$. Hasil analisis tersebut menunjukkan bahwa terdapat perbedaan yang signifikan terkait niat pemilihan jajanan sehat sebelum dan sesudah diberi pendidikan gizi dengan menggunakan metode TGT (Tabel 3).

Tabel 3. Niat Sebelum dan Sesudah Diberi Pendidikan Gizi

\begin{tabular}{lccc}
\hline \multicolumn{1}{c}{ Niat } & n & Median (min-maks) & $\boldsymbol{P}$ \\
\hline$\underline{\text { Ceramah }}$ & 16 & $47,0(30-55)$ & 0,01 \\
Sebelum & 16 & $49,5(40-54)$ & \\
Sesudah & & & \\
TGT & 26 & $50,0(35-55)$ & 0,027 \\
Sebelum & 26 & $52,5(44-55)$ & \\
Sesudah & &
\end{tabular}


Perbedaan Niat pada Kelompok Ceramah dan $\underline{\text { TGT }}$

Tabel 4 menunjukkan bahwa sebelum pemberian pendidikan gizi terdapat perbedaan niat yang signifikan antara kelompok ceramah dan kelompok Team Game Tournament (TGT) $(\mathrm{p}=0,026 ; \quad \mathrm{p}<0,05) . \quad$ Setelah pemberian pendidikan gizi tidak terdapat perbedaan yang signifikan antara kelompok ceramah dan Team Game Tournament (TGT). Baik sebelum maupun sesudah dilakukan perlakuan, kelompok TGT memiliki median yang lebih tinggi dibandingkan kelompok ceramah (Tabel 4).

Tabel 4. Niat Antara Kedua Kelompok Sebelum dan Sesudah Diberi Pendidikan Gizi

\begin{tabular}{lccc}
\hline \multicolumn{1}{c}{ Niat } & n & Median (min-maks) & $\boldsymbol{p}$ \\
\hline Sebelum & & & \\
Ceramah & 16 & $47,0(30-55)$ & 0,026 \\
TGT & 26 & $50,0(35-55)$ & \\
Sesudah & & & \\
Ceramah & 16 & $49,5(40-54)$ & 0,074 \\
TGT & 26 & $52,5(44-55)$ & \\
\hline
\end{tabular}

Perbedaan Selisih Nilai Niat pada Kelompok Ceramah dan TGT

Berdasarkan Tabel 5, selisih nilai niat tidak menunjukkan adanya perbedaan yang signifikan antara kelompok ceramah dan kelompok Team Game Tournament (TGT) $(\mathrm{p}=0,329 ; \mathrm{p}>0,05)$.
Namun berdasarkan nilai median masingmasing kelompok, kelompok ceramah memiliki median selisih yang lebih tinggi daripada kelompok Team Game Tournament (TGT), artinya peningkatan niat lebih tinggi terjadi pada kelompok ceramah (Tabel 5).

Tabel 5. Selisih Nilai Niat Sebelum dan Sesudah Diberi Pendidikan Gizi

\begin{tabular}{lccc}
\hline \multicolumn{1}{c}{ Selisih Niat } & $\mathbf{n}$ & Median (min-maks) & $\boldsymbol{P}$ \\
\hline Ceramah & 16 & $3,0((-4)-19)$ & 0,329 \\
TGT & 26 & $1,5((-5)-20)$ & \\
\hline
\end{tabular}

Berdasarkan Tabel 6, persentase responden yang mengalami peningkatan niat lebih banyak terdapat pada kelompok ceramah dibandingkan
Team Game Tournament (TGT), sedangkan baik penurunan maupun niat yang tetap lebih banyak terdapat pada kelompok TGT (Tabel 6).

Tabel 6. Perubahan Niat pada Kedua Kelompok Perlakuan

\begin{tabular}{ccccc}
\hline \multirow{2}{*}{ Niat } & \multicolumn{2}{c}{ Ceramah } & \multicolumn{3}{c}{ TGT } \\
\cline { 2 - 5 } & $\mathbf{n}$ & $\%$ & $\mathbf{n}$ & $\%$ \\
\hline Tetap & 1 & 6,2 & 3 & 11,5 \\
Meningkat & 12 & 75,0 & 15 & 57,7 \\
Menurun & 3 & 18,8 & 8 & 30,8 \\
Total & 16 & 100,0 & 26 & 100,0 \\
\hline
\end{tabular}

Perilaku Jajanan di Sekolah Sebelum dan Sesudah Diberi Pendidikan Gizi dengan Metode Ceramah dan TGT
Tabel 7 menunjukkan bahwa terjadi peningkatan nilai perilaku sebelum dan sesudah pemberian pendidikan gizi dengan metode ceramah. Peningkatan tersebut memiliki 
perbedaan yang signifikan $(\mathrm{p}<0,001 ; \mathrm{p}<0,05)$. Hasil analisis tersebut menunjukkan bahwa ada perbedaan yang signifikan terkait perilaku pemilihan jajanan sehat di sekolah sebelum dan sesudah diberi pendidikan gizi dengan metode ceramah. Median perilaku meningkat setelah diberi pendidikan gizi dengan metode ceramah.

Pada kelompok Team Game Tournament (TGT) menunjukkan bahwa terjadi peningkatan median nilai perilaku sebelum dan sesudah pemberian pendidikan gizi, peningkatan ini memiliki perbedaan yang signifikan $(\mathrm{p}<0,001$; $\mathrm{p}<0,05)$. Hasil analisis tersebut menunjukkan bahwa ada perbedaan yang signifikan terkait perilaku pemilihan jajanan sehat di sekolah sebelum dan sesudah diberi pendidikan gizi dengan metode Team Game Tournament (TGT) (Tabel 7).

Tabel 7. Perilaku Jajanan di Sekolah Sebelum dan Sesudah Diberi Pendidikan Gizi

\begin{tabular}{lccc}
\hline \multicolumn{1}{c}{ Perilaku Sekolah } & $\mathbf{n}$ & Median (min-maks) & $\boldsymbol{p}$ \\
\hline Ceramah & 16 & $5,0(3-6)$ & $<0,001$ \\
Sebelum & 16 & $7,0(6-9)$ & \\
Sesudah & & & \\
TGT & 26 & $4,0(0-8)$ & $<0,001$ \\
Sebelum & 26 & $8,0(6-9)$ & \\
Sesudah & &
\end{tabular}

Perbedaan Perilaku Jajanan di Sekolah pada Kelompok Ceramah dan TGT

Tabel 8 menunjukkan bahwa sebelum pemberian pendidikan gizi terdapat perbedaan yang signifikan terkait perilaku jajanan di sekolah antara kelompok ceramah dan TGT $(\mathrm{p}=0,003 ; \quad \mathrm{p}<0,05)$. Setelah pemberian pendidikan gizi juga terdapat perbedaan yang signifikan terkait perilaku jajanan di sekolah antara kelompok ceramah dan TGT ( $\mathrm{p}=0,043$; $\mathrm{p}<0,05)$. Sebelum diberi perlakuan kelompok ceramah memiliki median yang lebih tinggi dibandingkan kelompok Team Game Tournament (TGT), tetapi setelah perlakuan kelompok Team Game Tournament (TGT) memiliki median yang lebih tinggi dibandingkan kelompok ceramah (Tabel 8).

Tabel 8. Perilaku Jajanan di Sekolah antara Kedua Kelompok Sebelum dan Sesudah Diberi Pendidikan Gizi

\begin{tabular}{lccc}
\hline \multicolumn{1}{c}{ Perilaku Sekolah } & n & Median (min-maks) & $\boldsymbol{p}$ \\
\hline Sebelum & 16 & $5,0(3-6)$ & 0,003 \\
Ceramah & 26 & $4,0(0-8)$ & \\
TGT & & & \\
Sesudah & 16 & $7,0(6-9)$ & 0,043 \\
Ceramah & 26 & $8,0(6-9)$ & \\
TGT & &
\end{tabular}

Perbedaan Selisih Nilai Perilaku Jajanan $\underline{\text { Responden di Sekolah pada Kelompok Ceramah }}$ dan TGT

Berdasarkan Tabel 9 selisih nilai perilaku menunjukkan tidak berbeda signifikan antara kelompok ceramah dan kelompok Team Game Tournament (TGT) ( $\mathrm{p}=0,107 ; \mathrm{p}>0,05)$. Namun berdasarkan nilai rata-rata masingmasing kelompok, kelompok TGT memiliki rata-rata selisih yang lebih tinggi daripada kelompok ceramah, artinya peningkatan perilaku lebih tinggi terjadi pada kelompok TGT (Tabel 9).

Berdasarkan Tabel 10, persentase responden yang mengalami peningkatan perilaku lebih banyak terdapat pada kelompok ceramah dibandingkan Team Game Tournament (TGT), sedangkan responden yang memiliki perilaku yang tetap lebih banyak terdapat pada kelompok TGT (Tabel 10). 
Tabel 9. Selisih Nilai Perilaku antara Kedua Kelompok Sebelum dan Sesudah Diberi Pendidikan Gizi

\begin{tabular}{lccc}
\hline \multicolumn{1}{c}{ Selisih Perilaku } & N & Rerata \pm SD & $\boldsymbol{p}$ \\
\hline Ceramah & 16 & $3,44 \pm 1,153$ & 0,101 \\
TGT & 26 & $4,27 \pm 1,756$ & \\
\hline
\end{tabular}

Tabel 10. Perubahan Perilaku Jajanan di Sekolah Pada Kedua Kelompok Perlakuan

\begin{tabular}{lcccc}
\hline \multicolumn{1}{c}{ Perilaku Sekolah } & \multicolumn{2}{c}{ Ceramah } & \multicolumn{2}{c}{ TGT } \\
\cline { 2 - 5 } & $\mathbf{n}$ & $\mathbf{\%}$ & $\mathbf{n}$ & $\mathbf{\%}$ \\
\hline Tetap & 0 & 0,0 & 1 & 3,8 \\
Meningkat & 16 & 100,0 & 25 & 96,2 \\
Menurun & 0 & 0,0 & 0 & 0,0 \\
Total & 16 & 100,0 & 26 & 100,0 \\
\hline
\end{tabular}

Perilaku Jajanan Responden di Rumah Sebelum dan Sesudah Diberi Pendidikan Gizi dengan Metode Ceramah dan TGT

Tabel 11 menunjukkan bahwa terjadi peningkatan nilai perilaku jajanan di rumah sebelum dan sesudah pemberian pendidikan gizi dengan metode ceramah. Namun peningkatan ini tidak memiliki perbedaan yang signifikan $(\mathrm{p}=0,134 ; \mathrm{p}>0,05)$. Pada kelompok Team Game Tournament (TGT) menunjukkan bahwa tidak terjadi peningkatan ataupun penurunan nilai perilaku jajanan responden di rumah. Median nilai perilaku baik sebelum dan sesudah pemberian pendidikan gizi sama. Hasil analisis menunjukkan tidak ada perbedaan yang signifikan terkait perilaku jajanan responden di rumah sebelum dan sesudah pemberian pendidikan gizi dengan metode Team Game Tournament (TGT) $(\mathrm{p}=0,117 ; \mathrm{p}>0,05)$ (Tabel 11).

Tabel 11. Perilaku Jajanan di Rumah Sebelum dan Sesudah Diberi

\section{Pendidikan Gizi}

\begin{tabular}{lccc}
\hline \multicolumn{1}{c}{ Perilaku Rumah } & n & Median (min-maks) & $\boldsymbol{P}$ \\
\hline Ceramah & & & \\
Sebelum & 16 & $4,0(1-7)$ & 0,134 \\
Sesudah & 16 & $7,0(1-7)$ & \\
TGT & & & \\
Sebelum & 26 & $7,0(1-7)$ & 0,117 \\
Sesudah & 26 & $7,0(1-7)$ & \\
\hline
\end{tabular}

Perbedaan Perilaku Jajanan di Rumah pada Kelompok Ceramah dan TGT

Tabel 12 di bawah ini menunjukkan bahwa sebelum pemberian pendidikan gizi tidak ada perbedaan perilaku jajanan responden di rumah yang signifikan antara kelompok ceramah dan TGT $(p=0,105 ; p>0,05)$.
Selain itu juga setelah pemberian pendidikan gizi tidak ada perbedaan perilaku yang signifikan antara kedua kelompok perlakuan $(p=0,389 ; p>0,05)$. Namun sebelum pemberian pendidikan gizi, median TGT lebih tinggi dibandingkan kelompok ceramah (Tabel 12). 
Tabel 12. Perilaku Jajanan di Rumah Antara Kedua Kelompok Sebelum dan Sesudah Pendidikan Gizi

\begin{tabular}{lccc}
\hline \multicolumn{1}{c}{ Perilaku Rumah } & N & Median (min-maks) & $\boldsymbol{p}$ \\
\hline Sebelum & & & \\
Ceramah & 16 & $4,0(1-7)$ & 0,105 \\
TGT & 26 & $7,0(1-7)$ & \\
Sesudah & & & \\
Ceramah & 16 & $7,0(1-7)$ & 0,389 \\
TGT & 26 & $7,0(1-7)$ & \\
\hline
\end{tabular}

Perbedaan Selisih Perilaku Jajanan Responden di Rumah pada Kelompok Ceramah dan TGT

Berdasarkan Tabel 13, selisih nilai perilaku menunjukkan tidak adanya perbedaan yang signifikan antara kelompok ceramah dan kelompok TGT $(p=0,69 ; p>0,05)$.

Kelompok ceramah memiliki median selisih yang lebih tinggi daripada kelompok TGT, artinya peningkatan perilaku jajanan di rumah lebih tinggi terjadi pada kelompok ceramah daripada kelompok TGT (Tabel 13).

Berdasarkan tabel 14, persentase responden yang mengalami peningkatan dan penurunan perilaku lebih banyak terdapat pada kelompok ceramah. Sedangkan responden yang memiliki perilaku yang tetap lebih banyak terdapat pada kelompok TGT (Tabel 14).

Tabel 13. Selisih Nilai Perilaku Responden Sebelum dan Sesudah Diberi Pendidikan Gizi

\begin{tabular}{lccc}
\hline Selisih Perilaku & $\mathbf{n}$ & Median (min-maks) & $\boldsymbol{p}$ \\
\hline Ceramah & 16 & $1,5((-6)-6)$ & 0,690 \\
TGT & 26 & $0,0((-6)-6)$ & \\
\hline
\end{tabular}

Tabel 14. Distribusi Perubahan Perilaku Responden di Rumah Pada Kedua Kelompok

\begin{tabular}{lcccc}
\hline Perilaku Rumah & \multicolumn{2}{c}{ Ceramah } & \multicolumn{2}{c}{ TGT } \\
\cline { 2 - 5 } & $\mathbf{n}$ & $\mathbf{\%}$ & $\mathbf{n}$ & \% \\
\hline Tetap & 4 & 25 & 16 & 61,5 \\
Meningkat & 8 & 50 & 7 & 26,9 \\
Menurun & 4 & 25 & 3 & 11,5 \\
Total & 16 & 100 & 26 & 100 \\
\hline
\end{tabular}

\section{PEMBAHASAN}

\section{Karakteristik Responden berdasarkan Usia}

Responden pada kedua kelompok sebagian besar berusia 11 tahun. Usia merupakan faktor internal individu yang menentukan terjadinya perubahan perilaku [13]. Anak yang berada pada periode usia 6 sampai 14 tahun mulai matang untuk belajar serta merupakan periode intelektual [14].

Anak yang berusia 11 tahun mampu berpikir secara abstrak, menalar secara logis, dan menarik kesimpulan dari informasi yang tersedia [7]. Anak pada usia tersebut juga dapat berpikir secara rasional sehingga dapat menilai jenis jajanan yang akan dikonsumsi [15].

\section{Karakteristik Responden berdasarkan Jenis Kelamin}

Jenis kelamin responden pada kedua kelompok sebagian besar adalah laki-laki. Jenis kelamin dapat mempengaruhi daya terima seseorang untuk menerima informasi atau pengetahuan baru. Selain itu jenis kelamin juga mempengaruhi kondisi psikis seseorang. Pada umumnya laki-laki mempunyai sifat yang 
agresif dalam menerima hal-hal baru dan lebih menyukai tantangan daripada perempuan [13].

\section{Niat Responden yang Diberi Pendidikan Gizi dengan Metode Ceramah dan TGT}

Sebelum dilaksanakan pendidikan gizi, kelompok TGT memiliki median niat yang lebih tinggi daripada kelompok ceramah yang diduga disebabkan oleh siswa SDN Tumpakrejo 1 lebih banyak yang menggunakan media komunikasi elektronik sehingga lebih sering terpapar informasi terkait jajanan. Paparan media dan kemudahan akses terhadap informasi mampu mempengaruhi pengetahuan seseorang dan kemudian mempengaruhi niatnya [16]. Tingkat pendidikan guru juga berperan penting dalam mempengaruhi niat siswa dalam memilih jajanan. SDN Tumpakrejo 1 memiliki guru yang berpendidikan S1 lebih banyak daripada SDN Tumpakrejo 2. Semakin banyak guru yang berpendidikan tinggi, semakin banyak informasi dan pengetahuan terkait jajanan yang diberikan kepada siswa sehingga pengetahuan siswa terkait jajanan semakin luas karena semakin tinggi tingkat pendidikan seseorang, semakin tinggi tingkat pengetahuannya terkait jajanan sehat [5]. Berdasarkan sebuah penelitian terkait jajanan sehat, anak yang pernah memperoleh informasi mengenai jajanan sehat sebelumnya dari guru memiliki pengetahuan yang lebih baik dibandingkan dengan anak yang belum pernah memperoleh informasi sama sekali. Adanya informasi baru terkait jajanan sehat tersebut mampu memberikan landasan kognitif baru bagi terbentuknya pengetahuan anak dalam pemilihan jajanan sehat [17]. Disamping itu juga didukung oleh faktor kecerdasan kognitif siswa SDN Tumpakrejo 1 yang lebih baik dibandingkan SDN Tumpakrejo 2, dibuktikan dari segi prestasi akademik, siswa SDN Tumpakrejo 1 memiliki rata-rata nilai UN yang lebih tinggi dibandingkan SDN Tumpakrejo 2. Perilaku jajanan dipengaruhi oleh faktor yang berkaitan dengan karakteristik personal, salah satunya adalah kecerdasan [18]. Setelah pemberian pendidikan gizi, tidak terdapat perbedaan niat yang signifikan antara kelompok ceramah dan TGT. Selain itu, setelah dianalisis menggunakan uji Wilcoxon, baik pada kelompok ceramah maupun TGT, niat pemilihan jajanan sehat sebelum dan sesudah diberi pendidikan gizi masing-masing menunjukkan perbedaan yang signifikan. Namun kelompok ceramah memiliki median selisih yang lebih tinggi daripada kelompok TGT. Sedangkan dilihat dari jumlah responden yang mengalami peningkatan skor niat, kelompok ceramah lebih banyak yang mengalami peningkatan skor niat dibandingkan kelompok TGT. Oleh karena itu dapat dikatakan bahwa baik metode ceramah maupun TGT efektif dalam merubah niat pemilihan jajanan sehat tetapi peningkatan skor niat yang lebih tinggi dan jumlah responden yang mengalami peningkatan skor niat lebih banyak terjadi pada kelompok ceramah sehingga dapat disimpulkan bahwa kelompok ceramah memberikan hasil perubahan niat yang lebih baik daripada kelompok TGT. Hal ini diduga disebabkan oleh pada kelompok TGT beberapa responden masih merasa bingung terhadap prosedur pelaksanaan dan peraturan TGT karena belum pernah melakukan metode tersebut sebelumnya sehingga responden cenderung tidak fokus terhadap isi materi yang diberikan melainkan lebih fokus terhadap prosedur dan peraturan pelaksanaan TGT. Berdasarkan hasil penelitian terkait penggunaan metode TGT, kekurangan dari metode TGT adalah responden cenderung mengalami kesulitan dan merasa bingung terhadap pelaksanaan TGT sehingga mempengaruhi pemahaman responden terhadap materi yang diberikan [19]. Faktor lain diduga juga berperan dalam hasil penelitian yaitu responden pada kelompok ceramah cenderung lebih bersemangat ketika mendapatkan materi karena pelaksanaan pendidikan gizi dilakukan pada pagi hari sehingga mempengaruhi tingkat konsentrasi dan pemahaman responden terhadap materi. Sedangkan pada kelompok TGT pelaksanaan pendidikan gizi dilakukan pada siang hari menjelang pulang sehingga responden sudah merasa lelah yang berakibat pada tingkat konsentrasi dan pemahaman akan materi lebih rendah. Salah satu faktor yang mempengaruhi konsentrasi anak adalah temperatur di mana pada siang hari temperatur lebih tinggi daripada saat pagi hari [20]. Pada kelompok TGT pemberian pendidikan gizi dilakukan pada siang hari setelah responden mengalami kelelahan akibat beraktivitas fisik pada jam istirahat. Selain itu penelitian lain menunjukkan bahwa pada saat siang hari konsentrasi anak berada pada tingkat yang paling rendah [21]. Individu 
memiliki kapasitas perhatian yang terbatas yang disebabkan oleh faktor kelelahan, lapar serta akibat adanya gangguan penglihatan atau pendengaran akibat suara bising [22]. Selain beberapa faktor di atas, faktor lain yang mungkin berkontribusi adalah keadaan responden pada kelompok TGT lebih sulit dikendalikan karena jumlahnya yang lebih banyak dan situasi kelas yang kurang kondusif akibat faktor internal responden, sedangkan pada kelompok ceramah responden lebih mudah diatur dan jumlah responden lebih sedikit sehingga suasananya lebih kondusif. Keadaan responden merupakan faktor kunci dalam proses pendidikan gizi dan jumlah responden dapat mencerminkan keadaan responden di dalam kelas. Jumlah responden dapat mempengaruhi suasana kelas dan semakin banyak jumlah responden dalam suatu kelas akan menimbulkan kesulitan dalam mengontrol responden selama proses pendidikan gizi [13]. Hal ini juga diduga menyebabkan jumlah responden yang mengalami penurunan skor niat lebih banyak terjadi pada kelompok TGT disamping mungkin disebabkan karena interpretasi responden yang kurang tepat terhadap pernyataan niat yang diberikan [17]. Pada pemberian pendidikan gizi dengan metode ceramah dilakukan secara tatap muka sehingga penyuluh dapat secara langsung mengetahui respon responden yang diberi pendidikan gizi [9].

Pendidikan gizi menggunakan metode TGT memberikan kesempatan responden untuk bekerja sama memahami materi yang diberikan. Pada metode ini terjadi diskusi antar anggota kelompok dalam memecahkan persoalan yang diberikan. Selain itu terjadi kompetisi antar kelompok dalam memainkan permainan yang diberikan, sehingga responden menjadi lebih aktif dan pendidikan gizi menjadi tidak membosankan. Keterlibatan responden secara aktif dalam memecahkan persoalan ini berpeluang menambah pengetahuan dan pemahaman responden [23]. Retensi pengetahuan yang diakibatkan setelah pemberian pendidikan gizi menggunakan metode TGT sebesar $75 \%$, sesuai dengan hasil sebuah penelitian yang menyatakan bahwa pendidikan gizi dengan metode berbasis praktik menyebabkan retensi pengetahuan sebesar $75 \%$ [24].

\section{Perilaku Jajanan Responden di Sekolah yang Diberi Pendidikan Gizi dengan Metode Ceramah dan TGT}

Sebelum dilaksanakan pendidikan gizi, terdapat perbedaan yang signifikan antara kelompok ceramah dan TGT. Kelompok ceramah memiliki median perilaku yang lebih tinggi daripada kelompok TGT sebelum diberikan pendidikan gizi. Hal ini diduga disebabkan oleh dukungan yang lebih baik dari pihak SDN Tumpakrejo 2 terkait pemilihan jajanan sehat karena pihak SDN Tumpakrejo 2 terutama kepala sekolah sudah berusaha melarang beberapa penjual jajanan tidak sehat untuk tidak berjualan di sekitar sekolah meskipun masih terdapat beberapa penjual jajanan yang kurang mengindahkan larangan tersebut. Terbentuknya perilaku juga dipengaruhi oleh lingkungan, salah satunya adalah dukungan sosial [16]. Dalam hal ini dukungan yang paling berpengaruh selain keluarga adalah sekolah [18]. Di samping itu juga dapat disebabkan oleh pengaruh teman sebaya karena teman sebaya merupakan faktor sosial yang juga mampu mempengaruhi pemilihan makanan jajanan [25]. Meniru kebiasaan teman sebaya mempengaruhi anak dalam mengambil keputusan terkait pemilihan jajanan [18].

Setelah pemberian pendidikan gizi, perilaku responden antara kedua kelompok juga berbeda signifikan. Di samping itu, setelah dianalisis menggunakan uji Wilcoxon, baik pada kelompok ceramah maupun TGT, perilaku pemilihan jajanan sehat sebelum dan sesudah diberi pendidikan gizi masing-masing berbeda signifikan. Selisih antara perilaku sebelum dan sesudah perlakuan menunjukkan tidak ada perbedaan yang signifikan antara kelompok ceramah dan TGT. Kelompok TGT memiliki rata-rata selisih yang lebih tinggi daripada kelompok ceramah yang artinya peningkatan perilaku lebih tinggi terjadi pada kelompok TGT. Namun responden kelompok ceramah lebih banyak yang mengalami peningkatan perilaku daripada kelompok TGT. Dari hasil analisis data tersebut dapat dikatakan bahwa metode ceramah dan TGT keduanya mampu merubah perilaku. Metode TGT menyebabkan perubahan perilaku yang lebih baik dibandingkan metode ceramah tetapi metode ceramah menyebabkan responden yang 
mengalami perubahan perilaku lebih banyak dibandingkan TGT. Hal ini diduga disebabkan oleh sebelum pemberian pendidikan gizi kelompok ceramah sudah memiliki median perilaku yang tinggi sehingga range peningkatan skor perilaku yang diperlukan setelah pendidikan gizi pun tidak terlalu besar dibandingkan dengan kelompok TGT yang median perilaku awalnya lebih rendah. Hasil penelitian ini sejalan dengan sebuah penelitian terkait pengetahuan jajanan bahwa kelompok siswa yang memiliki rata-rata skor pretest lebih tinggi mengalami peningkatan skor lebih rendah dibandingkan kelompok siswa yang memiliki skor pretest lebih rendah [13]. Selain itu penelitian lain menyatakan bahwa skor pretest yang sudah tinggi menyebabkan range yang dibutuhkan untuk peningkatan skor lebih pendek [26].

Metode ceramah bisa digunakan pada sasaran baik yang berpendidikan tinggi maupun rendah dan sangat cocok digunakan pada pendidikan gizi. Kelebihan dari metode ini yaitu suasana kelas lebih tenang karena responden melakukan aktivitas yang sama sehingga responden dapat memahami isi materi yang diberikan dengan baik. Pemberian informasi dengan metode ceramah dapat menambah pengetahuan seseorang akan informasi terkait jajanan sehat [27]. Dalam prosesnya, perubahan pengetahuan itupun akan diikuti dengan perubahan niat dan pada akhirnya akan mampu mengubah perilaku membentuk suatu perilaku baru yang lebih baik sesuai tujuan awal pemberian pendidikan gizi [16]. Namun dalam beberapa penelitian, dengan penerapan metode tersebut tidak banyak memberikan perubahan yang signifikan pada responden. Hal tersebut dikarenakan pada metode ceramah yang berperan aktif adalah penyuluh untuk mempengaruhi responden. Selain itu beberapa kekurangan metode ceramah yang lain yaitu penyuluh kurang mengetahui secara pasti sejauh mana responden telah memahami materi, pemahaman responden berbeda dengan apa yang dimaksudkan oleh penyuluh kemungkinan dapat terjadi, responden cenderung merasa bosan serta responden kurang aktif sehingga pengetahuan dan pemahaman yang didapatkan oleh responden pun kurang matang dan akhirnya pengaruh terhadap perilaku responden juga kurang [27].
Pendidikan gizi menggunakan metode TGT memudahkan responden dalam memahami materi yang diberikan karena responden lebih aktif. Selain itu dengan menerapkan metode ini akan memacu kerja sama dan saling membantu antar responden dalam mengintegrasikan pengetahuan-pengetahuan baru dengan pengetahuan yang dimiliki [28]. Dengan bekal pengetahuan yang matang, perilaku responden pun mengalami perubahan yang lebih baik.

Responden juga belajar dan bekerja dalam kelompok-kelompok kecil untuk memahami materi pendidikan gizi yang diberikan. Dari kelompok perlakuan mayoritas berumur 11 tahun, usia ini berada pada tahap perkembangan sosial dan emosional yang mudah dibangkitkan semangatnya, menyukai kegiatan kelompok, dan loyal terhadap kelompoknya [29].

\section{Perilaku Jajanan Responden di Rumah yang Diberi Pendidikan Gizi dengan Metode Ceramah dan TGT}

Sebelum dilaksanakan pendidikan gizi, kedua kelompok perlakuan yaitu kelompok ceramah dan TGT tidak berbeda signifikan tetapi keduanya memiliki median perilaku yang berbeda. Kelompok TGT memiliki median perilaku yang lebih tinggi daripada kelompok ceramah sebelum diberikan pendidikan gizi. Hal ini diduga disebabkan oleh faktor tingkat pendidikan orang tua. Tingkat pendidikan orang tua siswa SDN Tumpakrejo 1 lebih tinggi daripada SDN Tumpakrejo 2. Pengetahuan tidak terlepas dari pendidikan. Peran orang tua terutama ibu untuk mengarahkan anaknya dalam pemilihan jajanan cukup besar. Orangtua terutama ibu yang memiliki pengetahuan baik tentang gizi dan ditunjang dengan pendidikan yang tinggi dapat memilih dan mengawasi jajanan yang dibeli oleh anaknya dengan lebih baik [18].

Setelah pemberian pendidikan gizi, perilaku responden antara kelompok ceramah dan kelompok TGT juga tidak berbeda signifikan. Selain itu, setelah dianalisis menggunakan uji Wilcoxon, baik pada kelompok ceramah dan TGT, perilaku pemilihan jajanan sehat sebelum dan sesudah diberi pendidikan gizi masing-masing menunjukkan hasil yang tidak berbeda signifikan. Selisih antara perilaku sebelum dan 
sesudah perlakuan menunjukkan tidak adanya perbedaan yang signifikan antara kelompok ceramah dan kelompok TGT.

Faktor yang diduga mempengaruhi hasil penelitian tersebut adalah sebelum diberi pendidikan gizi kualitas jajanan responden sudah cukup baik, responden lebih sering mengkonsumsi jajanan sehat di rumah. Hal ini diduga disebabkan oleh jajanan yang tersedia di rumah dan di lingkungan sekitar rumah sebagian besar berupa jajanan sehat sehingga responden mengkonsumsi jajanan yang sehat pula.

Kebiasaan seseorang berkaitan dengan karakteristik personal dan faktor lingkungan. Dalam hal ini lingkungan yang paling berpengaruh pada perilaku jajajan anak adalah keluarga. Selain itu faktor lain yang mempengaruhi pemilihan jajanan sehat adalah ketersediaan jajanan di rumah dan di lingkungan sekitar rumah serta adanya kesempatan untuk membeli [3]. Anak cenderung lebih memilih dan membeli jajanan yang tersedia paling dekat dengan keberadaannya [18].

Selain itu keterlibatan orang tua juga dapat mempengaruhi perilaku anak dalam memilih jajanan [25]. Anak-anak belum memiliki kontrol yang baik dalam membedakan jajanan yang sehat dan tidak sehat sehingga membutuhkan pendampingan dan pengawasan yang baik dari orangtua dalam memilih jajanan [18]. Di samping itu, faktor perilaku pemilihan jajanan orang tua juga berperan sebagai faktor penentu perilaku anak dalam memilih jajanan. Penelitian lain menunjukkan adanya hubungan yang kuat antara jenis jajanan yang dikonsumsi orang tua dengan jenis jajanan yang dikonsumsi oleh anak [30].

\section{KESIMPULAN}

Niat pemilihan jajanan sehat pada siswa kelas 5 SDN Tumpakrejo 2 meningkat setelah pemberian pendidikan gizi dengan metode ceramah. Begitu pula dengan SDN Tumpakrejo 1 mengalami peningkatan niat pemilihan jajanan sehat setelah diberi pendidikan gizi dengan metode TGT. Kedua metode tersebut efektif dalam merubah niat tetapi metode ceramah memberikan hasil perubahan niat yang lebih baik dibandingkan TGT.

Selain itu, baik metode ceramah maupun TGT juga sama-sama efektif dalam merubah perilaku pemilihan jajanan di sekolah walaupun pada kelompok ceramah lebih banyak responden yang mengalami peningkatan nilai. Peningkatan nilai responden pada kelompok TGT lebih tinggi dibandingkan kelompok ceramah. Namun, pendidikan gizi dengan menggunakan metode ceramah dan TGT ini kurang efektif dalam mengubah perilaku jajanan di rumah. Beberapa faktor diduga mempengaruhinya.

\section{UCAPAN TERIMA KASIH}

Penulis mengucapkan terima kasih kepada Kepala SDN Tumpakrejo 1 dan SDN Tumpakrejo 2 Kabupaten Malang atas kesempatan yang telah diberikan kepada kami sehingga dapat melaksanakan penelitian di sekolah yang beliau pimpin.

\section{DAFTAR RUJUKAN}

1. Badan Pengawas Obat dan Makanan Republik Indonesia. Info POM: Pentingnya Promosi Keamanan Pangan di Sekolah untuk Menyelamatkan Generasi Penerus. Jakarta; 2011.

2. Badan Pengawas Obat dan Makanan Republik Indonesia. LAPTAH: Laporan Tahunan 2011 Badan Pengawas Obat dan Makanan RI. Jakarta; 2011.

3. Chi-Ming,Wei L, Hsiao-Chi Y, Wen-Harn P. The Relationship between Snack Intake and Its Availability of 4th-6th Graders in Taiwan. Asia Pasific Journal of Clinical Nutrition. 2007; 16 (S2): 547-553.

4. Khomsan A. Teknik Pengukuran Pengetahuan Gizi. Bogor: Fakultas Ekologi Manusia Institut Pertanian Bogor; 2000.

5. Notoatmodjo S. Ilmu Perilaku Kesehatan. Jakarta: PT. Rineka Cipta; 2010. 146-147.

6. Sangperm P. Predicting Adolescent Healthy Eating Behavior Using Attitude, Subjective Norm, Intention, and Self-Schema [Thesis]. Bangkok: Mahidol University; 2006. Available from: http://deepblue.lib.umich.edu.

7. Patterson CJ. Child Development. New York: McGraw Hill; 2008. 23.

8. Wulandari A. Peningkatan Pengetahuan Gizi pada Anak Sekolah dengan Metode Ceramah dan Role Play [Skripsi]. Semarang: Universitas Diponegoro; 2007. Available from: http://eprints.undip.ac.id. 
9. Pasaribu HER. Perbandingan Penyuluhan Kesehatan Metode Ceramah Tanya Jawab Dengan Penyuluhan Kesehatan Menggunakan Buku Kecacingan Dalam Mencegah Reinfeksi Ascaris lumbricoides pada Anak Sekolah Dasar [Tesis]. Semarang: Universitas Diponegoro; 2005. Available from: http://eprints.undip.ac.id.

10. Mulyatiningsih E. Pembelajaran Aktif, Kreatif, Inovatif, Efektif, dan Menyenangkan (PAIKEM). Dalam: Diklat Peningkatan Kompetensi Pengawas dalam Rangka Penjaminan Mutu Pendidikan Direktorat Jenderal Peningkatan Mutu Pendidikan dan Kependidikan. Yogyakarta: UNY; 2010. Available from: http://staff.uny.ac.id.

11. Vaus DE. Research Design in Social Research. London: Sage Publications; 2005. 79.

12. Hayati M. Pengaruh Peer Edukasi Pentingnya Gizi terhadap Perilaku Anak Usia Sekolah dalam Menentukan Jajanan Sehat di Kota Lhokseumawe [Thesis]. Jakarta: Universitas Indonesia; 2009. Available from: http://lib.ui.ac.id.

13. Amalia N. Perbedaan Skor Pengetahuan Gizi antara Siswa yang Diberikan Penyuluhan dengan Metode Ceramah dan Siswa yang diberikan Penyuluhan dengan Metode "Playing by Learning" Melalui Media "Seri Petualangan Dino dan DinaSaatnya Sehat" di Sekolah Dasar Jakarta Timur Tahun 2008 [Skripsi]. Jakarta: Universitas Islam Negeri Syarif Hidayatullah; 2008. Available from: http://perpus.fkik.uinjkt.ac.id.

14. Hapsari II dan Suminar DR. Efektifitas Ludo Word Game terhadap Peningkatan Kosakata Bahasa Inggris pada Anak Studi Kasus pada Siswa Kelas IV SD Muhammadiyah 4 Pucang. 2003; 5 (1): 116.

15. Purtiantini. Hubungan Pengetahuan dan Sikap Mengenai Pemilihan Makanan Jajanan dengan Perilaku Anak Memilih Makanan di SDIT Muhammadiyah Al Kautsar Gampang Kartasura [Skripsi]. Surakarta: Universitas Muhammadiyah; 2010. Available from: http://eprints.ums.ac.id.
16. Contento IR. Nutrition Education: Linking Research, Theory, and Practice. Asia Pacific Journal of Clinical Nutrition. 2008; 17 (1): 176-179.

17. Saputri LO, Kristiawati, Krisnana Ilya. Peningkatan Pengetahuan dan Sikap dalam Pemilihan Jajanan Sehat Menggunakan Alat Permainan Edukatif Ular Tangga. Indonesian Journal of Community Health Nursing. 2012; 1 (1): 1-10.

18. Aprilia BA. Faktor yang Berhubungan dengan Pemilihan Makanan Jajanan pada Anak Sekolah Dasar [Skripsi]. Semarang: Universitas Diponegoro; 2011. Available from: http://eprints.undip.ac.id.

19. Kuwati M, Susiani TS, Suyanto I. Model Pembelajaran TGT dalam Peningkatan Pembelajaran PKN Siswa Kelas IV Sekolah Dasar. Jurnal Kalam Cendekia PGSD Kebumen. 2012; 1 (2): 1-6.

20. Hakim T. Mengatasi Gangguan Konsentrasi Plus Teknik-Teknik Latihan Konsentrasi. Jakarta: Puspa Swara; 2002. 1-18.

21. Bell WS. Influence of Time-of-Day on Students Performance on Mathematical Algorithms [Thesis]. California: University of California; 2005. Available from: http://files.ed.gov.

22. Djamaludin MD, Simanjuntak M, Rochimah N. Pengaruh Motivasi Pesan dan Penyajian Buklet terhadap Persepsi dan Pengetahuan tentang Jajanan Sehat. Jurnal Ilmu Keluarga dan Konsumen. 2012; 5 (1): 67-76.

23. Suryani. Efektivitas Pembelajaran Kooperatif Tipe Team Game Tournament (TGT) dan Numbered Heads Together (NHT) terhadap Keaktifan dan hasil Belajar Matematika Siswa Kelas VII SMP Muhammadiyah 8 Yogyakarta. [Skripsi]. Yogyakarta: Universitas Islam Negeri Sunan Kalijaga; 2013. Available from: http://digilib.uin-suka.ac.id.

24. Tran VD. The Effects of Cooperative Learning on the Academic Achievement and Knowledge Retention. International Journal of Higher Education. 2014; 3 (2): 131-140.

25. Taylor JP, Evers S, McKenna M. Determinants of Healthy Eating in Children and Youth. Canadian Journal of Public Health. 2005; 96 (3): 20-26.

26. Townsend MS, Johns M, Shilts MK, FarfanRamirez L. Evaluation of a USDA Nutrition 
Education Program for Low-income Youth. Journal of Nutrition Education Behaviour. 2006; 38: 30-41.

27. Qiftiyah M. Perbedaan Penyuluhan dengan Metode Ceramah dan Diskusi terhadap Perilaku Merokok di SMA Negeri 4 Tuban [Skripsi]. Tuban; 2012. Available from: http://lppm.stikesnu.com.

28. Sari REK. Upaya Peningkatan Hasil Belajar dengan Menggunakan Model Pembelajaran Kooperatif Team Games Tournament. Economic Education Analysis Journal Sains dan Teknologi Universitas Islam Negeri Sunan Kalijaga. 2012; 1 (1): 1-7.

29. Budiman D. Bahan Ajar M.K Psikologi Anak dalam Penjas PGSD. Jakarta: EGC; 2007.

30. Brown R, Ogden J. Children's Eating Attitudes and Behaviour: A Study of the Modelling and Control Theories of Parental Influence. Health and Education Research. 2004; 19 (3): 261-271. 